\title{
Pengembangan Layout Interior Pesawat N219 Air Ambulance untuk Meningkatkan Teamwork Tim Paramedis Udara pada Proses Transfer Antar Rumah Sakit
}

\author{
Fahriza Prima Abdillah, Andhika Estiyono, dan Muji Hendro \\ Departemen Desain Produk, Fakultas Arsitektur Desain dan Perencanaan, \\ Institut Teknologi Sepuluh Nopember (ITS) \\ e-mail: andhika@prodes.its.ac.id
}

\begin{abstract}
Abstrak-Indonesia sebagai negara berkembang masih memiliki berbagai masalah pada aspek pelayanan medis. Banyak daerah di Indonesia tidak memiliki fasilitas medis yang memadai. Rendahnya ketersediaan ambulans menyebabkan penduduk di daerah terpencil mengalami kesulitan mengakses fasilitas kesehatan. Ambulans udara membantu mengoptimalkan mobilisasi ambulans sebagai sarana warga dalam mengakses layanan kesehatan ketika mentransfer lebih dari $241 \mathrm{~km}$ dengan perawatan medis. Transfer antar rumah sakit memfasilitasi transfer pasien dari rumah sakit daerah terpencil ke rumah sakit pusat atau rumah sakit spesialis untuk perawatan khusus. Desain kabin ambulans udara untuk transfer antar rumah sakit di Indonesia sebagian besar kurang mempertimbangkan formasi yang sesuai untuk mendukung tugas paramedis. Hal ini dapat menyebabkan ketidaksesuaian aktivitas dan peralatan medis yang diperlukan sehingga dapat menghambat aktivitas dan kerjasama paramedis dalam penanganan kepada pasien. Metode penelitian dilakukan dengan mengumpulkan data melalui metode seperti Contextual Inquiry, User Journey Map, Deep Interview, dan User Stories. Tujuan dari penelitian ini adalah mengembangkan desain interior pesawat N219 sebagai ambulans udara dalam rangka mempermudah tim paramedis udara untuk melakukan kerjasama, komunikasi internal, dan tetap berfokus pada pasien selama on flight treatment.
\end{abstract}

Kata Kunci-ambulans udara, transfer antar rumah sakit, interior, layout.

\section{PENDAHULUAN}

TNONESIA sebagai negara berkembang dengan penduduk 255.741.973 jiwa menempati posisi ke 4 terbesar di dunia [1].

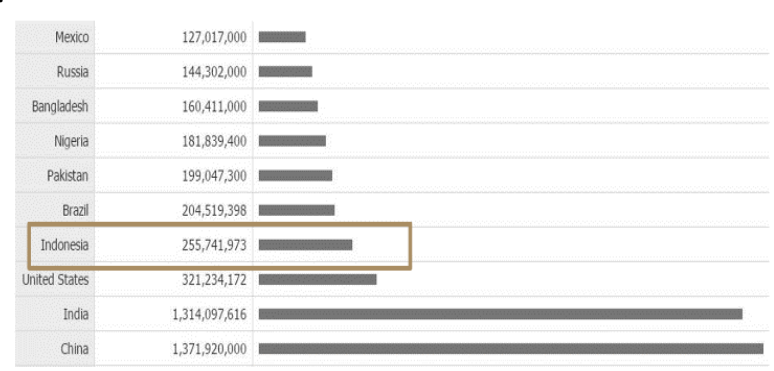

Gambar 1. 10 besar urutan negara dengan jumlah populasi terbesar.[1]

Indonesia masih menghadapi berbagai masalah dalam aspek layanan kesehatan. Disparitas status kesehatan di antara tingkat sosial ekonomi, antar daerah, dan antar-perkotaan-pedesaan masih cukup tinggi.

Rasio Sarana Pelayanan Kesehatan dengan Jumlah Penduduk di Beberapa Provinsi di Indonesia Bagian Timur = Rumah Sakit = Puskesmas

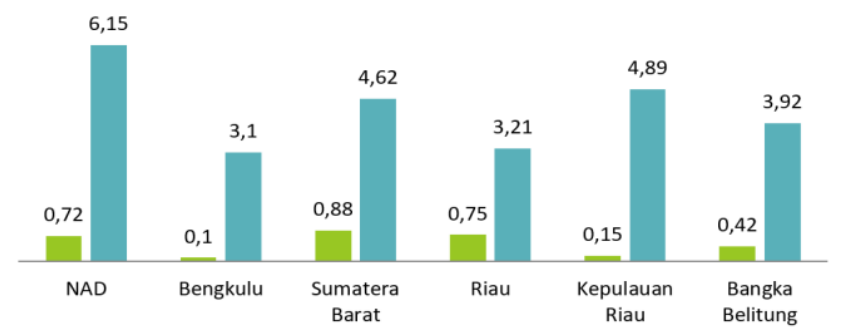

Gambar 2. Grafik rasio sarana pelayanan kesehatan dengan jumlah Penduduk di beberapa Provinsi di Indonesia Bagian Timur.

Di Indonesia dan di negara-negara berkembang lainnya pada umumnya, transportasi sering menjadi hambatan dalam layanan kesehatan [2]. Karena itu tidak sedikit kasus kesehatan terutama kasus darurat yang berujung pada kematian. Penggunaan Ambulans Udara secara efektif dioperasikan ketika pasien diminta untuk melakukan perjalanan lebih dari $241,40 \mathrm{~km}$ dan memerlukan perawatan medis yang cepat [3]. Operasi transfer antar rumah sakit memfasilitasi pasien untuk dirujuk dari pusat kesehatan atau rumah sakit terpencil untuk rehabilitasi khusus di mana fasilitas kesehatan di lokasi pasien tidak dapat menangani atau memberikan medical treatment yang sesuai [4]. Kebutuhan untuk mendesain kabin pesawat udara untuk Ambulans Udara yang sesuai dengan karakteristik dan ukuran berdasarkan antropometri orang Indonesia dan alur komunikasi tim adalah penting untuk mendukung semua kegiatan di kabin. Maka dari itu dibutuhkan pembaruan layout yang berhubungan dengan perawatan medis dan kabin operasional dasar dalam rangka mempermudah tim paramedis udara untuk melakukan kerjasama, komunikasi internal, dan tetap berfokus pada pasien selama on flight treatment.

\section{METODOLOGI}

Dari implementasi metode diagram pada gambar 3 dan gambar 4, serangkaian metode yang lebih spesifik digunakan untuk men generate idea dan konsep. Diantaranya adalah metode sebagai berikut. 


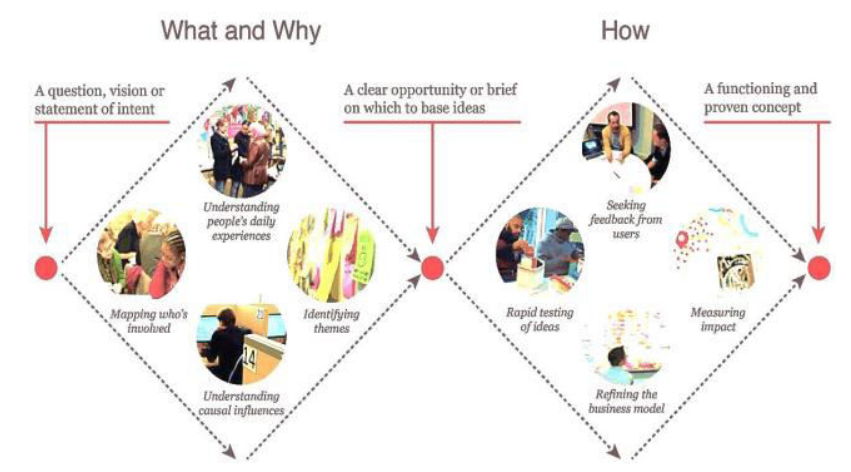

Gambar 3. Diagram metode what, why, and how.

\section{A. Contextual Inquiry}

Metode kontekstual yang implementasinya adalah mewawancarai dan mengamati untuk mengungkapkan struktur kerja operasional Air Ambulance [5]. Memahami cara kerja dan peran personel Paramedis dalam melakukan kegiatan mereka masing-masing serta apa saja kontak fisik atau interaksinya dengan lingkungan kabin dan peralatannya serta komunikasi antara awak kabin satu sama lain dan pengaruhnya di lingkungan kabin pesawat.

\section{B. User Journey Map}

Metode representasi fisik dari skenario yang didapat dari metode Constextual Inquiry, yang divisualisasikan menjadi sebuah alur tindakan atau kegiatan personil maupun instansi dari berbagai pihak yang terkait dalam satu kesatuan operasi prosedur ambulans udara transfer antar rumah sakit [6].

\section{Deep Interview}

Metode yang mempertanyakan dan menjawab metode dalam konteks mendiskusikan sesuatu yang mendalam, sehingga hasilnya dapat mengungkapkan apa kebutuhan pengguna baik secara implisit maupun eksplisit yang ditangkap oleh desainer. Adapun rincian metode ini adalah penulis mengajukan pertanyaan terkait dengan Apa, Siapa, Kapan, Dimana, Mengapa, Bagaimana.

\section{User Stories}

Metode yang pada intinya narasumber akan menceritakan apa pun berdasarkan keinginannya untuk berbagi cerita tentang ikhtisar dan rincian monolog. Dalam konteks ini, narasumber menceritakan kisah berdasarkan waktu yang ditentukan secara komprehensif. Adapun rincian metode ini adalah setiap personel tim Paramedis menceritakan apa pun sesuai kehendaknya dimana yang terkait dengan topik rancangan kabin ambulans udara dalam operasi transfer antar rumah sakit [7].

\section{KONSEP DAN ANALISA}

Konsep layout kabin mengusung upaya peningkatan kerjasama tim paramedis, yang diharapkan mampu memberikan kemudahan yang lebih baik ketika pengguna atau petugas paramedis melakukan penanganan medis berkat adanya komunikasi serta interaksi yang terjalin dengan baik di dalam kabin selama operasi transfer antar rumah sakit [8].
Kajian diawali dengan urutan prosedur operasi transfer rumah sakit yang berlaku di Indonesia. Berdasarkan observasi serta pengaplikasian beberapa metode kepada tim Evakuasi Medis Udara TNI-AL yang bermarkas di Lanudal Juanda Surabaya, diperoleh bahwa pada umumnya di Indonesia baik sipil maupun militer memiliki kesamaan prosedur dan cara penanganan pada proses transfer antara rumah sakit. Berikut adalah data hasil penerapan metode dalam studi ini.

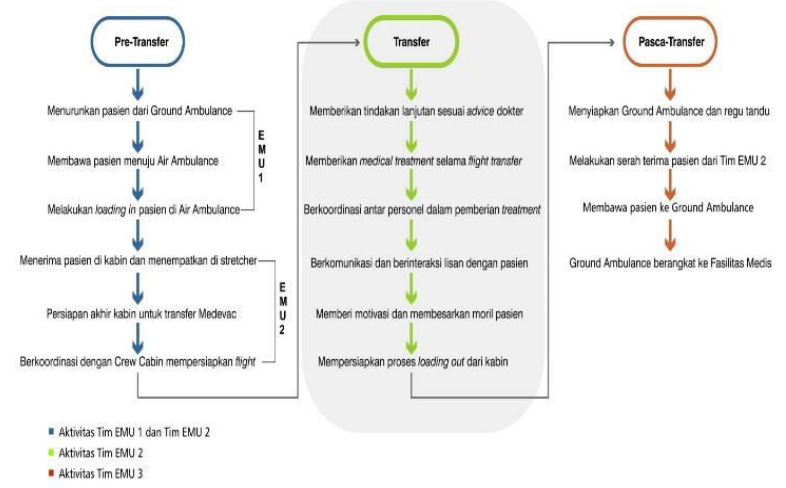

Gambar 4. Alur prosedur transfer antar rumah sakit di Indonesia.

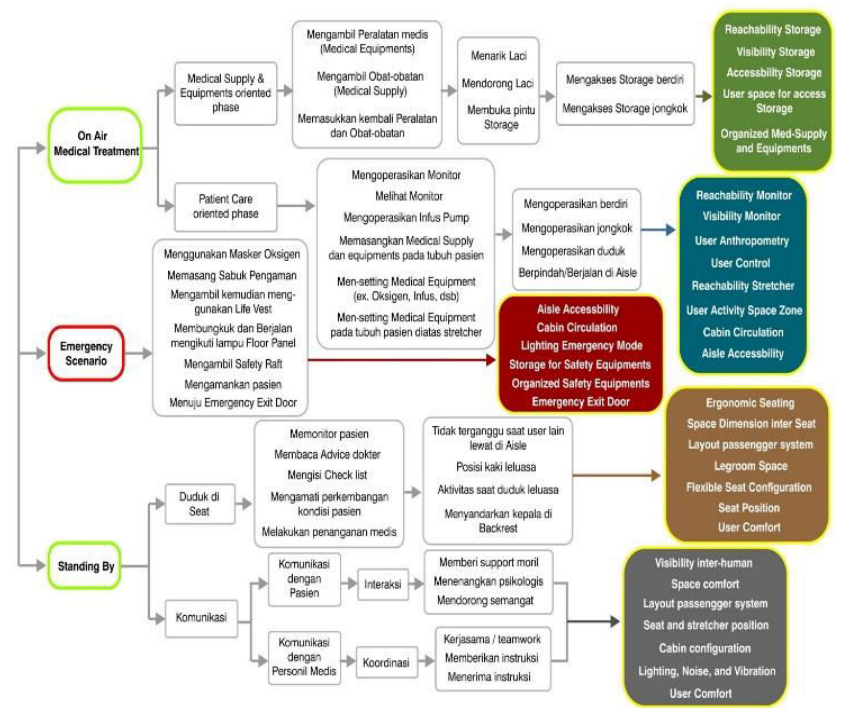

Gambar 5. Skema breakdown aktivitas paramedis dalam kabin selama transfer on flight.

Berikut alur operasional prosedur transfer antar rumah sakit. Berdasarkan pengukuran ketinggian pada 3 subjek yang tergabung dalam tim Evakuasi Medis Udara serta visualisasi terukur cross section kabin pesawat N219, didapat data sebagai berikut.

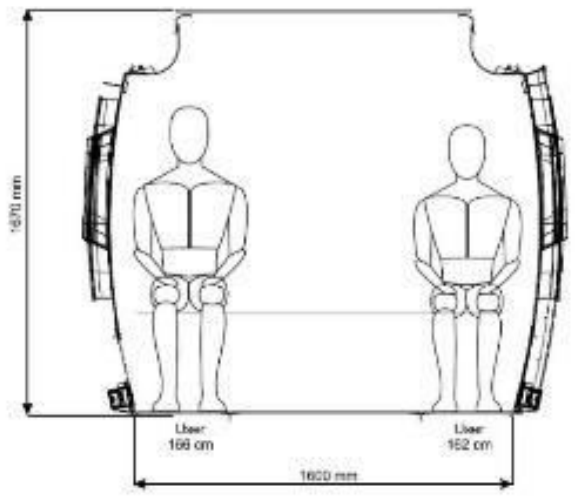




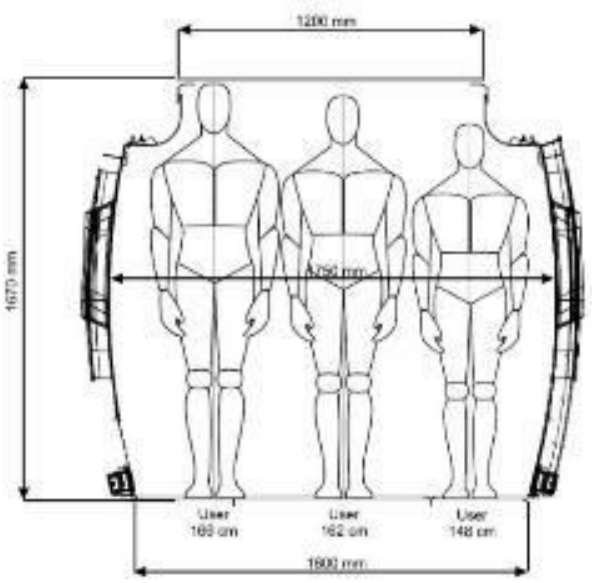

Gambar 6. Perbandingan ukuran anthropometri orang Indonesia dengan kabin pesawat N219.

Tabel 1.

Ukuran dimensi tubuh orang Indonesia untuk keperluan aktivitas dalam ruang kabin pesawat.

\begin{tabular}{|c|c|c|c|}
\hline No & Dimensi Tubuh & $\begin{array}{c}\text { Acuan Pria/Wanita } \\
\text { (Persentil) yang } \\
\text { Digunanakan }\end{array}$ & Dimensi (cm) \\
\hline 1 & Tinggi tubuh & Pria 50th & 165.95 \\
\hline 2 & Tinggi mata, berdiri & Wanita 5 th & 122.98 \\
\hline 3 & Tinggi pundak, berdiri & Wanita 50th & 119.51 \\
\hline 4 & Tinggi Siku, berdiri & Wanita 5 th & 83 \\
\hline 5 & Tinggi Pinggang, berdiri & Wanita 5th & 78 \\
\hline 6 & $\begin{array}{l}\text { Jangkauan lengan atas, } \\
\text { berdiri }\end{array}$ & Wanita 5th & 149.88 \\
\hline 7 & $\begin{array}{l}\text { Jangkauan lengan } \\
\text { kedepan, berdiri }\end{array}$ & Wanita 5th & 6.60 \\
\hline 8 & Tinggi saat duduk & Wanita 5th & 118.91 \\
\hline 9 & Tinggi pundak, duduk & Wanita 50th & 94.67 \\
\hline 10 & Tinggi siku, duduk & Wanita 50th & 69.20 \\
\hline 11 & Tinggi popliteal, duduk & Pria 5th & 40 \\
\hline 12 & Lebar pinggul, duduk & Wanita 95th & 47 \\
\hline 13 & $\begin{array}{l}\text { Jangkauan lengan atas, } \\
\text { duduk }\end{array}$ & Wanita 5th & 39.10 \\
\hline 14 & $\begin{array}{ll}\text { Jangkauan } & \text { lengan } \\
\text { kedepan, duduk } & \end{array}$ & Wanita 5th & 6.60 \\
\hline 15 & Lebar pundak, duduk & Pria 95th & 49.14 \\
\hline 16 & $\begin{array}{l}\text { Panjang buttock ke } \\
\text { popliteal }\end{array}$ & Pria 95th & 49.00 \\
\hline
\end{tabular}

Pada studi pengembangan ini, spesifikasi layout yang akan diterapkan adalah sebagai berikut.

Tabel 2.

Spesifikasi batasan kabin untuk pengembangan air ambulance

\begin{tabular}{cc}
\hline \hline Panjang Kabin & $6.5 \mathrm{~meter}$ \\
Lebar Kabin & $1.8 \mathrm{~meter}$ \\
Tinggi Kabin & $1.7 \mathrm{~meter}$ \\
Jarak Seat Pitch & $74 \mathrm{~cm}$ \\
Lebar Aisle & $48 \mathrm{~cm}$ \\
Stretcher & 2 unit \\
Seat & 4 unit \\
Pasien & $1-2$ orang \\
Personil Medis & $2-3$ orang \\
Pintu Emergency Exit & 1 unit di tiap sisi \\
\hline \hline
\end{tabular}

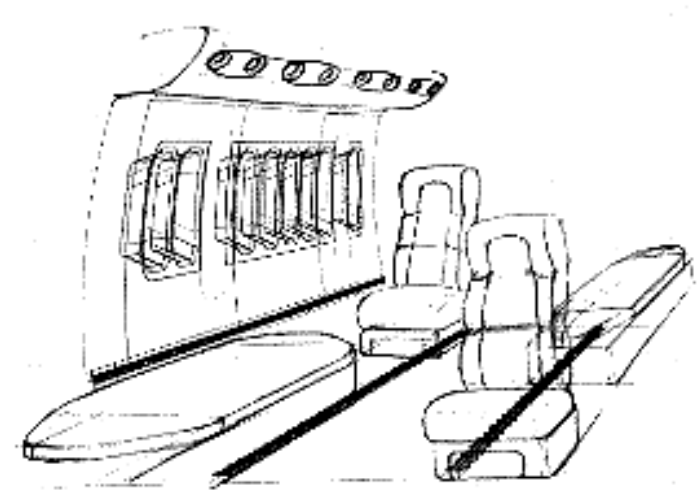

Gambar 7. Sketsa visualisasi rencana layout.

Untuk studi persona kepada subjek user didapat data sebagai berikut.

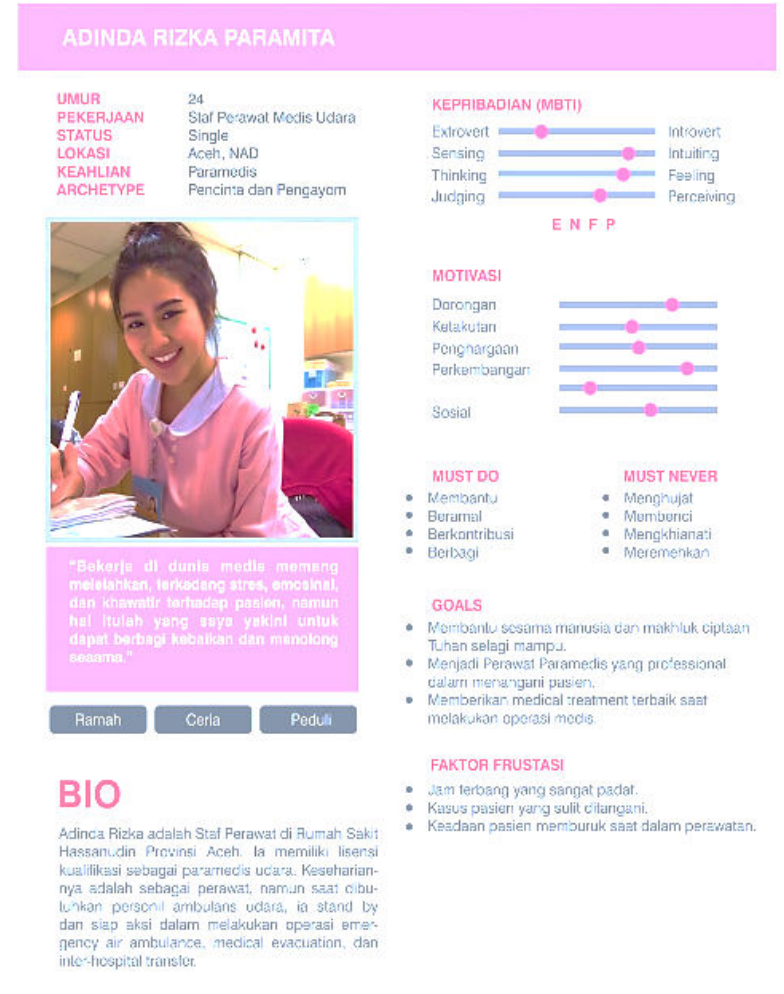

IV. HASIL DESAIN

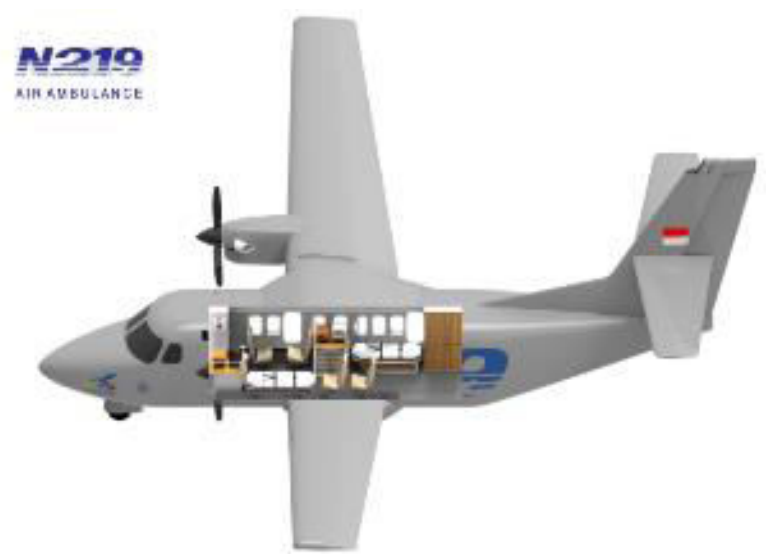




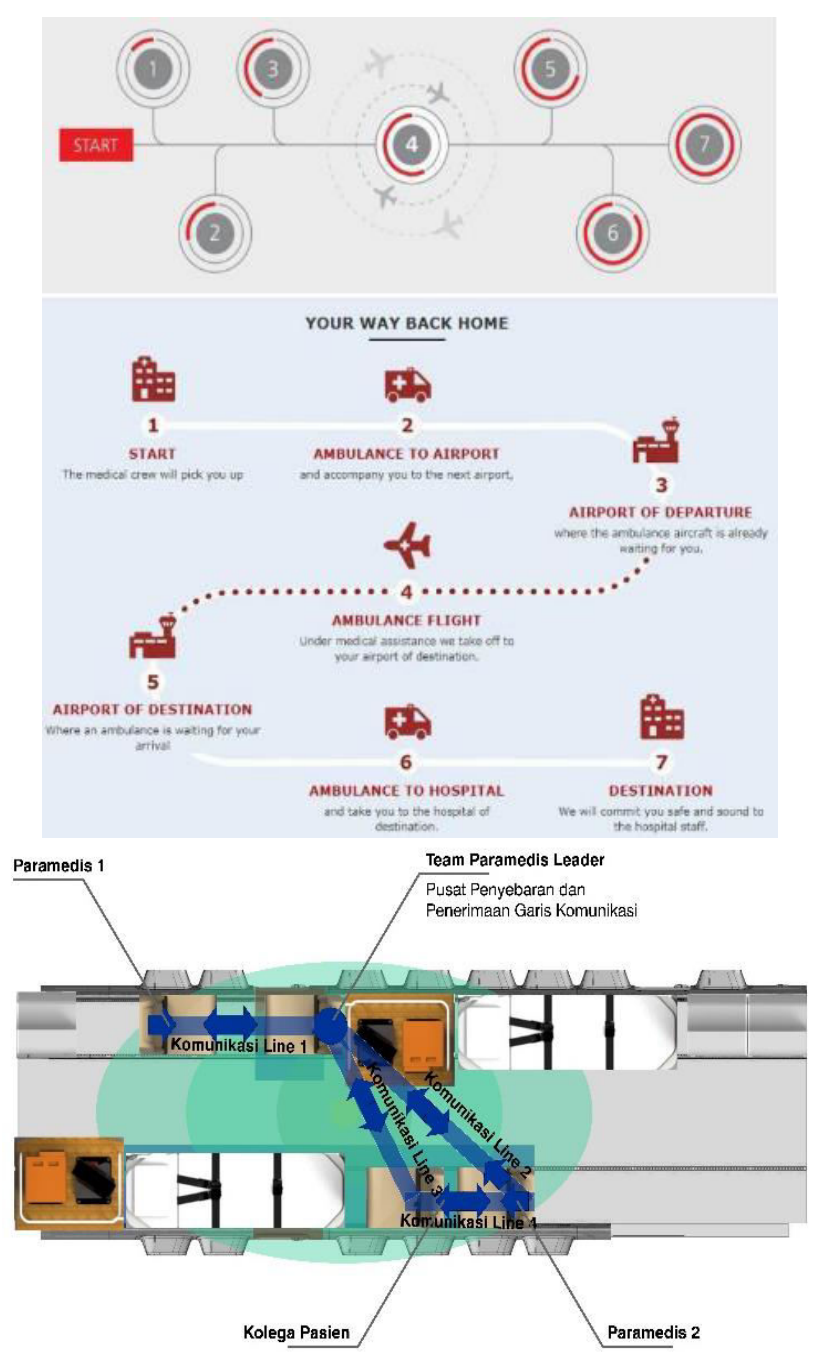

Gambar 8. Hasil pengembangan layout air ambulance.

Berikut penjelasan hasil pengembangan layout air ambulance.

Terdapat 4 jalur komunikasi yang saling terintegrasi.

1. Terdapat 4 posisi dalam kabin yang masing-masing memilki peran tersendiri.

2. Posisi pemimpin tim paramedis diantara paramedis 1 , paramedis 2, dan kolega pasien. Berperan sebagai pusat penyebaran informasi dan penerimaan inormasi baik dari paramedis 1, paramedis 2, dan kolega pasien. Posisi ini mendistribusikan informasi secara komprehensif agar komunikasi dan interaksi tim saling terintegrasi. Posisi ini juga bertugas memberikan instruksi pada tiap pengambilan keputusan. Alur distribusi komunikasi pada pemimpin tim paramedis adalah jalur komunikasi 1 , jalur komunikasi 2, jalur komunikasi 3.

3. Posisi paramedis 1 sebagai paramedis yang berinteraksi langsung dengan pasien 1, yang kemudian akan melaporkan informasi kepada pemimpin tim serta menerima keputusan tiap tindak lanjut dari pemimpin tim. Alur distribusi komunikasi pada paramedis 1 adalah jalur komunikasi 1.
4. Posisi paramedis 2 sebagai paramedis yang berinteraksi langsung dengan pasien 2, yang kemudian akan melaporkan informasi kepada pemimpin tim serta menerima keputusan tiap tindak lanjut dari pemimpin tim. Namun terdapat perbedaan dengan paramedis 1, paramedis 2 dapat berinteraksi dan berkomunikasi dengan kolega pasien, dimana informasi yang didapat dan diteruskan untuk kepentingan kelancaran penanganan medis. Alur distribusi komunikasi pada paramedis 1 adalah jalur komunikasi 2 dan jalur komunikasi 4.

5. Posisi kolega pasien sebagai pemberi informasi yang berkaitan dengan pasien, dimana dalam penanganan medis udara yang serba cepat.

6. Informasi yang hanya diketahui oleh kolega pasien sangatlah penting untuk diinformasikan kepada tim paramedis. Selain itu, posisi ini juga menerima informasi tentang kondisi pasien secara berkala dari pemimpin tim paramedis. Alur distribusi komunikasi pada kolega pasien adalah jalur komunikasi 3 dan jalur komunikasi 4.

Tabel 3.

Ukuran dimensi ergonomi ruang dan aktivitas dalam kabin pesawat

\begin{tabular}{|c|c|c|c|}
\hline No & Dimensi Produk & $\begin{array}{c}\text { Acuan Desain } \\
\text { Kriteria } \\
\text { Pria/Wanita } \\
\text { Persentil } \\
\end{array}$ & $\begin{array}{l}\text { Rekomendasi } \\
\text { Dimensi }(\mathrm{cm})\end{array}$ \\
\hline 1 & Tinggi Storage & $\begin{array}{l}\text { Tinggi bahu } \\
\text { dari lantai, 5th } \\
\text { persentil } \\
\text { Wanita }\end{array}$ & 80 \\
\hline 2 & Tinggi dudukan Seat & $\begin{array}{l}\text { Tinggi popliteal } \\
\text { saat duduk 5th } \\
\text { persentil Pria }\end{array}$ & 41 \\
\hline 3 & Tinggi Meja & $\begin{array}{c}\text { Tinggi siku saat } \\
\text { duduk } 95 \text { th } \\
\text { persentil } \\
\text { Wanita }\end{array}$ & 49.5 \\
\hline 4 & Tinggi Bed / Stretcher & $\begin{array}{c}\text { Tinggi siku saat } \\
\text { duduk 5th } \\
\text { persentil } \\
\text { Wanita }\end{array}$ & 51.5 \\
\hline 5 & $\begin{array}{l}\text { Panjang kedalaman } \\
\text { dudukan Seat }\end{array}$ & $\begin{array}{l}\text { Panjang buttock } \\
\text { ke popliteal } \\
\text { 95th persentil } \\
\text { Pria }\end{array}$ & 49 \\
\hline 6 & Lebar dudukan Seat & $\begin{array}{l}\text { Lebar pinggul } \\
\text { saat duduk 95th } \\
\text { persentil } \\
\text { Wanita }\end{array}$ & 47 \\
\hline 7 & Tinggi Arm rest & $\begin{array}{c}\text { Tinggi siku saat } \\
\text { duduk } 5 \text { th } \\
\text { persentil } \\
\text { Wanita }\end{array}$ & 19.5 \\
\hline 8 & $\begin{array}{l}\text { Tinggi Back rest } \\
\text { diatas dudukan Seat }\end{array}$ & $\begin{array}{l}\text { Tinggi pundak } \\
\text { 95th persentil } \\
\text { Wanita }\end{array}$ & 78 \\
\hline 9 & $\begin{array}{l}\text { Tinggi Monitor } \\
\text { (untuk dioperasikan } \\
\text { duduk) }\end{array}$ & $\begin{array}{c}\text { Tinggi mata } \\
\text { saat duduk 50th } \\
\text { persentil } \\
\text { Wanita }\end{array}$ & 72 \\
\hline 10 & $\begin{array}{l}\text { Tinggi Monitor } \\
\text { (untuk dioperasikan } \\
\text { berdiri) }\end{array}$ & $\begin{array}{l}\text { Tinggi pundak } \\
\text { saat beridiri } 5 \text { th } \\
\text { persentil }\end{array}$ & 117 \\
\hline
\end{tabular}




\begin{tabular}{|c|c|c|c|}
\hline & & Wanita & \\
\hline 11 & $\begin{array}{c}\text { Tinggi tombol pada } \\
\text { panel / Passenger } \\
\text { Service Unit }\end{array}$ & $\begin{array}{l}\text { Tinggi mata } \\
\text { pada saat } \\
\text { berdiri 50th } \\
\text { persentil } \\
\text { Wanita }\end{array}$ & 146 \\
\hline 12 & Panjang Cabinet & $\begin{array}{c}\text { Jangkauan saat } \\
\text { berdiri 50th } \\
\text { persentil } \\
\text { Wanita }\end{array}$ & 45 \\
\hline 13 & Tinggi Cabinet & $\begin{array}{c}\text { Tinggi siku saat } \\
\text { bersiri 5th } \\
\text { persentil } \\
\text { Wanita }\end{array}$ & 88 \\
\hline
\end{tabular}

Desain layout yang menitikberatkan perpaduan antara Kapabilitas pesawat N219, karakteristik fisik serta ukuran kabin N219, pengaplikasian standar regulasi yang berlaku. Dengan pengaplikasian konsep layout pada gambar 8, dapat meningkatkan fungsi integrasi dalam tim personel paramedis dimana dapat berinteraksi dan berkomunikasi dalam tim dan dengan pasien secara terstruktur, mudah dan nyaman. Dengan demikian pengembangan layout akan menciptakan cara kerja yang interaktif dan komunikatif dalam proses transfer antar rumah sakit sehingga meningkatkan teamwork dalam tim paramedis. Desain kabin yang demikian akan memungkinkan kemudahan, ketepatan, dan kenyamanan yang lebih tinggi saat personil paramedis mengakses storage untuk mencari bahan medis dan mengoperasikan medical equipment.

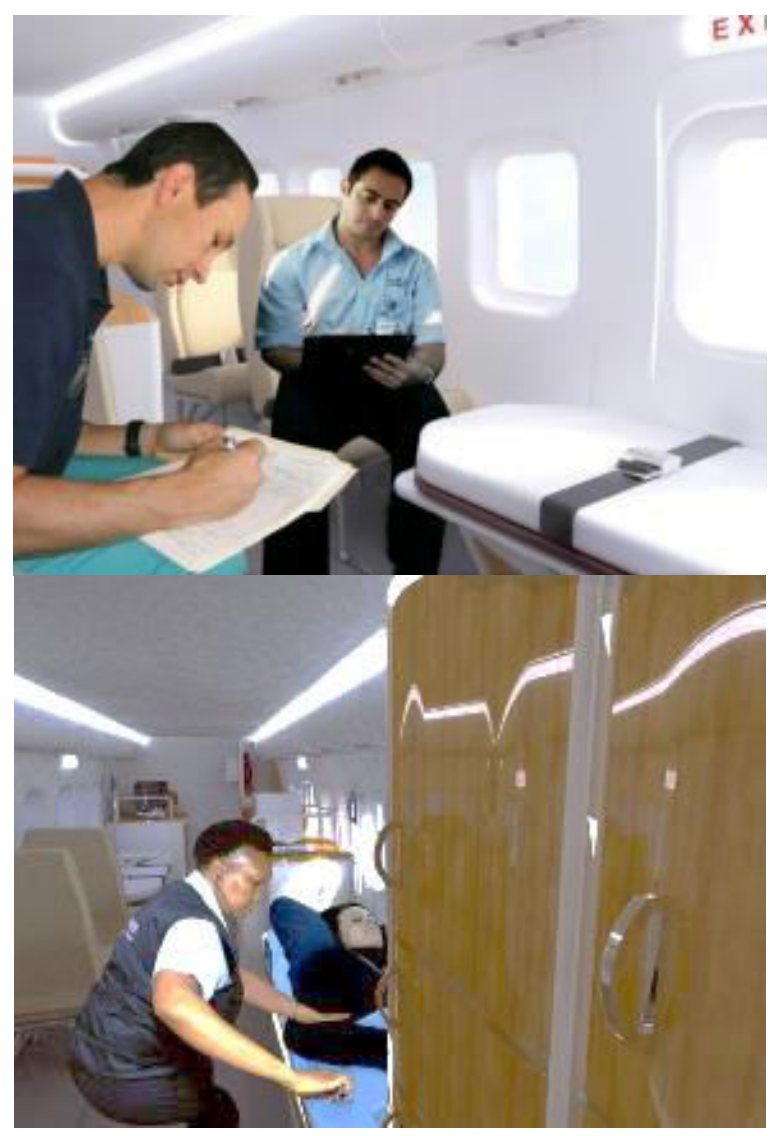

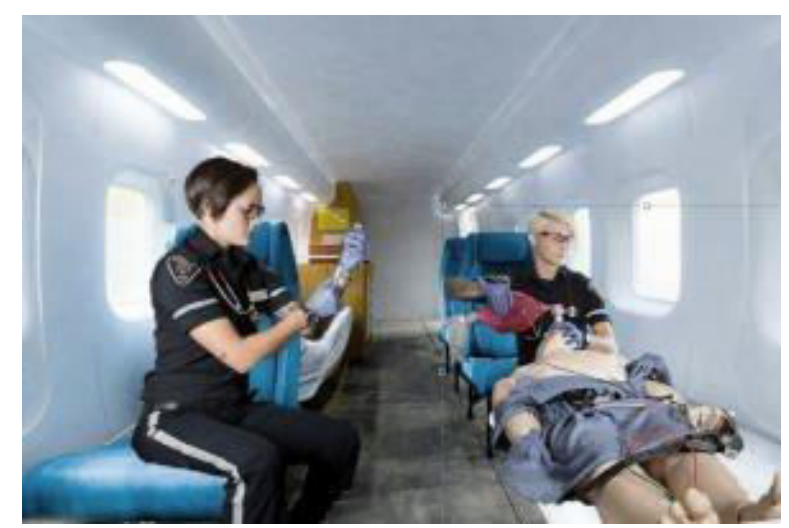

Gambar 9. Ilustrasi pengaplikasian layout hasil pengembangan dalam operasi transfer antar rumah sakit.

\section{KESIMPULAN}

Mengeksplorasi ide dan pemecahan masalah melalui metode desain dapat mengembangkan pengaplikasian konsep layout yang memfasilitasi aktivitas dan interaksi antara tim paramedis dan pasien dalam penanganan medical treatment transfer antar rumah sakit selama di pesawat. Pengembangan ini akan membantu meningkatkan kualitas hidup orang yang tinggal di daerah terpencil, meningkatkan aksesibilitas masyarakat terpencil untuk mencapai layanan medis yang layak. Penulis berharap dengan artikel ini dapat dijadikan sebagai ilmu pengetahuan bagi masyarakat, mahasiswa, dan praktisi dibidang transportasi umum khususnya transportasi pesawat di Indonesia sebagai bentuk pengembangan tranportasi pesawat. Penulis berharap akan ada kritik dan saran balik yang membangun dari pelaku industri, pakar, dan peneliti untuk dapat lebih menyempurnakan pengetahuan dan penelitian yang nantinya akan berguna untuk mengembangkan produk kedepannya.

\section{DAFTAR PUSTAKA}

[1] P. R. Beureu, "World Population Data Sheet," 2015.

[2] H. Herman, "Evaluasi Kebijakan Penempatan Tenaga Kesehatan di Puskesmas Sangat Terpencil di Kabupaten Buton," J. Manaj. Pelayanan Kesehat., 2008.

[3] C. Moga, Air Ambulance with Advance Life Support. New York, 2008.

[4] B. Elias, The Safety of Air Ambulance. California: CRS, The Library of Congress, 2006.

[5] S. Thomas and A. Arthur, "Helicopter EMS: Research Endpoints and Potential Benefits," 2012.

[6] S. Jelleh, "Redesigning EMS in USA," 2014.

[7] T. Iwashyana and A. Courey, Guided Transfer for Critically III Patient: Where Patient are Transferred Can be Informed. Brooklyn: Curr Opin, 2011.

[8] J. Wagner and J. Kahn, Reasons Underlying Interhospital Transfers to an Academic Medical Intensive Care Unit. Chicago: Crit Care Press, 2013. 